\title{
CLINICAL STUDY AND MANAGEMENT OF VENTRAL HERNIAS IN ADULTS
}

\author{
S. S. Karbhari', Umeshchandra D. G², Srikanth Marla Chintamani ${ }^{3}$
}

1 Professor, Department of General Surgery, Mahadevappa Rampure Medical College.

2 Professor and HOD, Department of General Surgery, Mahadevappa Rampure Medical College.

${ }^{3}$ Postgraduate Student, Department of General Surgery, Mahadevappa Rampure Medical College.

\begin{tabular}{l}
\hline ABSTRACT \\
BACKGROUND \\
Hernia is defined as abnormal protrusion of viscous through a normal or abnormal weakness in the wall of its containing cavity. \\
Ventral hernias are the second most common type of hernias accounting for $21 \%$ to $35 \%$ of all varieties of hernias. Reported \\
incidence of incisional hernias is $2 \%$ to $11 \%$. It is the most common complication after laparotomy by a $2: 1$ ratio over bowel \\
obstruction and is the most common indication for reoperation by $3: 1$ ratio over adhesive small bowel obstruction. \\
This study was undertaken to study the various clinical presentation and management of ventral hernias.
\end{tabular}

\section{MATERIALS AND METHODS}

This is a prospective study. A clinical study of 50 cases of ventral hernia has been done during the period from December 2015 to September 2017, on inpatients admitted to Basaveshwar Teaching and General Hospital (BTGH) attached to Mahadevappa Rampure Medical College, Gulbarga. Data was collected according to proforma, which included detailed history, clinical examination and investigation. Data was tabulated, analysed and results interpreted.

\section{RESULTS}

Incidence of incisional hernias was more in females with male-to-female ratio of 1: 4, while epigastric and umbilical hernias were more common in males with male-to-female ratio of 3: 1 and 2: 1 respectively. Previous surgery was the single most important cause for ventral (Incisional) hernias. Other aetiological factors were multiparity, obesity, anaemia, BPH, alcoholic liver disease and COPD. Postoperative wound infection was the important cause for development of incisional hernias. Size of the defect and presence of complication are the guiding factors for choosing the type of repair. Mesh repair is the technique of choice for most of incisional hernias and for all ventral hernias with large defect. Though sublay/ underlay mesh placement is more physiological, it can be placed either inlay or onlay.

\section{CONCLUSION}

Ventral hernias are common surgical complaints. Prevention is the better treatment in the form of meticulous dissection and proper post-operative care. Presence of ventral hernia is an indication for surgery even in presence of co-morbid conditions like ascites, COPD and BPH, as these patients are more prone for complications and of course these conditions need proper addressal before hernia repair. Mesh repair has become the standard of care and laparoscopy is the approach of choice depending on the affordability of the patients and expertise of the surgeon.

\section{KEYWORDS}

Ventral Hernias, Incisional Hernias, Mesh Repair, Suture Repair.

HOW TO CITE THIS ARTICLE: Karbhari SS, Umeshchandra DG, Chintamani SM. Clinical study and management of ventral hernias in adults. J. Evolution Med. Dent. Sci. 2018;7(04):449-453, DOI: 10.14260/jemds/2018/100

\section{BACKGROUND \\ Objectives}

Billroth told his pupil Czerny: "If we could artificially produce tissues of the density and toughness of fascia and tendon, the secret of the radical cure of hernia would be discovered." Synthesis of plastic began in the twentieth century and nylon was the first material widely available as suture. Publications document the use of nylon mesh during World War II in France. Unfortunately, nylon loses tensile strength due to hydrolysis and denaturation and is associated with hernia recurrence. During the 1950s and 1960s, polypropylene and Dacron were introduced. 1

'Financial or Other Competing Interest': None.

Submission 12-12-2017, Peer Review 05-01-2018,

Acceptance 11-01-2018, Published 22-01-2018.

Corresponding Author:

Dr. Srikanth Marla Chintamani,

Department of General Surgery

2nd floor, BTGH,

Kalburgi.

E-mail: srikudude@gmail.com

DOI: $10.14260 /$ jemds $/ 2018 / 100$

1. To study the modes of presentations, risk factors and predisposing factors and complications of ventral hernias.

2. To study various surgical options, currently available to treat ventral hernias and the changing trends.

\section{MATERIALS AND METHODS}

This is a prospective study. A clinical study of 50 cases of ventral hernia has been done during the period from December 2015 to September 2017, on inpatients admitted to Basaveshwar Teaching and General Hospital (BTGH) attached to Mahadevappa Rampure Medical College, Gulbarga. The study was approved by Ethics Committee of the hospital and informed written consent was obtained from all patients. A simple random sampling was done for selecting the patients.

The patient related factors namely age, sex, multiparity, obesity, cough/ COPD, constipation, prostatism, diabetes mellitus, hypertension, steroid therapy, consumption of tobacco and alcohol and past surgical history were recorded. 
A Master Chart has been made recording relevant history and findings of personally studied 50 cases of ventral hernia. Routine investigations viz. Haematology, Urine examination, Chest x-ray, ECG, Ultrasound abdomen and Pelvis for all patients and other special investigations were done for associated diseases wherever required.

As clinical diagnosis was made, patients with medical illness were appropriately treated to attain near normal parameters before surgery. At the induction of anaesthesia, prophylactic dose of antibiotic (3rd generation cephalosporin) was given. Patients were assigned to undergo suture repair or mesh repair at operating surgeon's discretion.

In suture repair, continuous stitches with stitch width and interval approximately $1 \mathrm{~cm}$ was put using polypropylene (Prolene No. 1). In mesh repair, Prolene mesh was used with at least $4 \mathrm{~cm}$ of mesh overlapping the edges of the facial defect and secured with No. 1 Prolene.

\section{Attention was given to Study various aspects of Ventral} Hernias like-

1. Distribution of ventral hernias with respect to age and sex of the patient.

2. Types of hernia.

3. Period between the previous surgery and the development of incisional hernia.

4. Aetiological/ predisposing factors for the development of ventral hernias.

5. Common presentations.

6. Exact location and size of the defect.

7. Various surgical options for the management of ventral hernias.

8. Complications in the perioperative period.

Follow-up was done at 1, 6, 12 and 18 months of interval following surgery. Descriptive and inferential statistical analysis has been carried out in the present study. The results were analysed by using SPSS version 18 (IBM Corporation, SPSS Inc. and Chicago, IL, USA). Microsoft Word and Excel was used to generate graphs, tables, etc. Results on continuous measurements were presented on Mean \pm SD (Min-Max) and results on categorical measurements were presented in Number (\%). Chi-square test with Yate's correction and Fisher Exact test was applied to check the difference between the groups for different parameters.

\section{RESULTS}

\begin{tabular}{|c|c|c|}
\hline Age (Years) & Frequency & Percentage \\
\hline $21-30$ & 06 & 12 \\
\hline $31-40$ & 07 & 14 \\
\hline $41-50$ & 16 & 32 \\
\hline $51-60$ & 11 & 22 \\
\hline $61-70$ & 06 & 12 \\
\hline $71-80$ & 04 & 08 \\
\hline Total & $\mathbf{5 0}$ & $\mathbf{1 0 0}$ \\
\hline Mean \pm Sd (Range) & $48.78 \pm 13.67(22-75)$ \\
\hline \multicolumn{2}{|c|}{ Table 1. Age Distribution } \\
\hline
\end{tabular}

\begin{tabular}{|c|c|c|}
\hline Gender & Frequency & Percentage \\
\hline Female & 30 & 60 \\
\hline Male & 20 & 40 \\
\hline Total & $\mathbf{5 0}$ & $\mathbf{1 0 0}$ \\
\hline \multicolumn{3}{|c|}{ Table 2. Gender Distribution } \\
\hline
\end{tabular}

\begin{tabular}{|c|c|c|c|c|}
\hline \multirow{2}{*}{$\begin{array}{c}\text { Age } \\
\text { (Years) }\end{array}$} & Gender & & & \multirow{2}{*}{$P$ value } \\
\hline & Female & Male & Total & \\
\hline $21-30$ & 04 & 02 & 06 & \multirow{7}{*}{0.999} \\
\hline $31-40$ & 04 & 03 & 07 & \\
\hline $41-50$ & 09 & 06 & 15 & \\
\hline $51-60$ & 07 & 05 & 12 & \\
\hline $61-70$ & 04 & 02 & 06 & \\
\hline $71-80$ & 02 & 02 & 04 & \\
\hline Total & 30 & 20 & 50 & \\
\hline Inference & \multicolumn{4}{|c|}{$\begin{array}{c}\text { There is no statistically significant difference in } \\
\text { distribution for the gender in different age } \\
\text { groups }\end{array}$} \\
\hline
\end{tabular}

\begin{tabular}{|c|c|c|}
\hline & Frequency & Percentage \\
\hline Swelling over abdomen & 34 & 78 \\
\hline $\begin{array}{c}\text { Swelling over abdomen and } \\
\text { pain }\end{array}$ & 04 & 08 \\
\hline Swelling over umbilicus & 11 & 22 \\
\hline $\begin{array}{c}\text { Swelling over umbilicus and } \\
\text { pain }\end{array}$ & 01 & 02 \\
\hline Total & $\mathbf{5 0}$ & $\mathbf{1 0 0}$ \\
\hline \multicolumn{2}{|c|}{ Table 4. Presenting Complaints } \\
\hline
\end{tabular}

\begin{tabular}{|c|c|c|c|c|}
\hline & \multicolumn{2}{|c|}{ Gender } & \multirow{2}{*}{ Total } & \multirow{2}{*}{$P$ value } \\
\hline & Female & Male & & \\
\hline $\begin{array}{l}\text { Swelling over } \\
\text { abdomen }\end{array}$ & 23 & 11 & 34 & \multirow{5}{*}{0.659} \\
\hline $\begin{array}{c}\text { Swelling over } \\
\text { abdomen and pain }\end{array}$ & 03 & 01 & 04 & \\
\hline $\begin{array}{c}\text { Swelling over } \\
\text { umbilicus }\end{array}$ & 04 & 07 & 11 & \\
\hline $\begin{array}{c}\text { Swelling over } \\
\text { umbilicus and pain }\end{array}$ & 0 & 01 & 01 & \\
\hline Total & 30 & 20 & 50 & \\
\hline Inference & $\begin{array}{r}\text { There } \\
\text { diff } \\
\text { com }\end{array}$ & $\begin{array}{l}\text { no sta } \\
\text { rence f } \\
\text { laints a }\end{array}$ & $\begin{array}{l}\text { ically si } \\
\text { he pres } \\
\text { ng the }\end{array}$ & $\begin{array}{l}\text { nificant } \\
\text { nting } \\
\text { nder }\end{array}$ \\
\hline
\end{tabular}

\begin{tabular}{|c|c|c|}
\hline & Frequency & Percentage \\
\hline Irreducible swelling & 03 & 06 \\
\hline Obstruction & 02 & 04 \\
\hline Uncomplicated & 45 & 90 \\
\hline Total & $\mathbf{5 0}$ & $\mathbf{1 0 0}$ \\
\hline \multicolumn{2}{|c|}{ Table 6. Associated Complication } \\
\hline
\end{tabular}

\begin{tabular}{|c|c|c|c|c|}
\hline & \multicolumn{2}{|c|}{ Gender } & \multirow[t]{2}{*}{ Total } & \multirow[t]{2}{*}{ P value } \\
\hline & Female & Male & & \\
\hline $\begin{array}{l}\text { Irreducible } \\
\text { swelling }\end{array}$ & 02 & 01 & 03 & \multirow[t]{4}{*}{0.845} \\
\hline Obstruction & 01 & 01 & 02 & \\
\hline Uncomplicated & 27 & 18 & 45 & \\
\hline Total & $\mathbf{5 0}$ & 100 & $\mathbf{5 0}$ & \\
\hline Inference & \multicolumn{4}{|c|}{$\begin{array}{c}\text { There is no statistically significant difference } \\
\text { for associated complications among the } \\
\text { gender }\end{array}$} \\
\hline \multicolumn{5}{|c|}{ Table 7. Gender-Wise associated Complications } \\
\hline
\end{tabular}

\begin{tabular}{|c|c|c|}
\hline Type of Ventral Hernia & Frequency & Percentage \\
\hline Epigastric hernia & 10 & 20 \\
\hline Incisional hernia & 28 & 56 \\
\hline Paraumbilical hernia & 12 & 24 \\
\hline Total & $\mathbf{5 0}$ & $\mathbf{1 0 0}$ \\
\hline \multicolumn{2}{|c|}{ Table 8. Diagnosis } \\
\hline
\end{tabular}




\begin{tabular}{|c|c|c|c|c|}
\hline Type of Ventral Hernia & \multicolumn{2}{|c|}{ Gender } & \multirow{2}{*}{ Total } & \multirow{2}{*}{$\begin{array}{c}\mathbf{P} \\
\text { value }\end{array}$} \\
\hline & Female & Male & & \\
\hline Epigastric hernia & 03 & 07 & 10 & \multirow{4}{*}{0.001} \\
\hline Incisional hernia & 23 & 05 & 28 & \\
\hline Paraumbilical hernia & 04 & 08 & 12 & \\
\hline Total & 30 & 20 & 50 & \\
\hline Inference & $\begin{array}{l}\text { There is } \\
\text { differenc } \\
\text { ventral h }\end{array}$ & $\begin{array}{l}\text { atistica } \\
\text { or the } \\
\text { nia typ } \\
\text { gend }\end{array}$ & $\begin{array}{l}\text { ly sign } \\
\text { listribu } \\
\text { es amo } \\
r\end{array}$ & $\begin{array}{l}\text { ficant } \\
\text { tion of } \\
\text { ng the }\end{array}$ \\
\hline
\end{tabular}

Table 9. Gender-Wise distribution of Ventral Hernia Types

\begin{tabular}{|c|c|c|}
\hline & Frequency & Percentage \\
\hline $\begin{array}{c}\text { Alcoholic liver disease } \\
\text { (Ascites) }\end{array}$ & 03 & 06 \\
\hline Anaemia & 03 & 06 \\
\hline BPH & 04 & 08 \\
\hline COPD & 03 & 06 \\
\hline Obesity & 09 & 18 \\
\hline Previous Surgery & 28 & 56 \\
\hline Total & $\mathbf{5 0}$ & $\mathbf{1 0 0}$ \\
\hline \multicolumn{2}{|c}{ Table 10. Predisposing Factor } \\
\hline
\end{tabular}

\begin{tabular}{|c|c|c|}
\hline & Frequency & Percentage \\
\hline Appendicectomy & 01 & 3.57 \\
\hline Hysterectomy & 08 & 28.57 \\
\hline Laparotomy & 07 & 25 \\
\hline LSCS & 07 & 28 \\
\hline Tubectomy & 05 & 17.86 \\
\hline Total & $\mathbf{2 8}$ & $\mathbf{1 0 0}$ \\
\hline Table 11. Types of Surgeries causing Ventral Hernia \\
\hline
\end{tabular}

\begin{tabular}{|c|c|c|}
\hline & Frequency & Percentage \\
\hline$<6$ Months & 04 & 14.28 \\
\hline 6 Months - 1 Year & 02 & 07.14 \\
\hline 1- 5 Years & 09 & 32.15 \\
\hline 5-10 Years & 04 & 14.28 \\
\hline$>10$ Years & 09 & 32.15 \\
\hline Total & 28 & 100 \\
\hline \multicolumn{3}{|c|}{$\begin{array}{c}\text { Table 12. Time Period of Onset of Ventral Hernia after } \\
\text { Surgery }\end{array}$} \\
\hline
\end{tabular}

\begin{tabular}{|c|c|c|}
\hline & Frequency & Percentage \\
\hline$<10 \mathrm{~cm}$ & 26 & 52 \\
\hline $11-20 \mathrm{~cm}$ & 14 & 28 \\
\hline $21-30 \mathrm{~cm}$ & 06 & 12 \\
\hline $31-40 \mathrm{~cm}$ & 02 & 04 \\
\hline$>40 \mathrm{~cm}$ & 02 & 04 \\
\hline Total & 50 & 100 \\
\hline Mean \pm SD & $\mathbf{1 3 . 4 0 \pm 7 . 8 6}$ (5-46 Days) \\
\hline \multicolumn{3}{|c|}{ Table 13. Size of Defect } \\
\hline
\end{tabular}

\begin{tabular}{|c|c|c|}
\hline & Frequency & Percentage \\
\hline Anatomical repair & 03 & 06 \\
\hline Mayo's repair & 02 & 04 \\
\hline Mesh repair & 45 & 90 \\
\hline Total & $\mathbf{5 0}$ & $\mathbf{1 0 0}$ \\
\hline \multicolumn{3}{|c|}{ Table 14. Surgery Done } \\
\hline
\end{tabular}

\begin{tabular}{|c|c|c|c|c|}
\hline & \multicolumn{2}{|c|}{ Gender } & \multirow{2}{*}{ Total } & \multirow{2}{*}{ P value } \\
\cline { 2 - 3 } & Female & Male & & \\
\hline $\begin{array}{c}\text { Anatomical } \\
\text { repair }\end{array}$ & 0 & 3 & 3 & \multirow{2}{*}{0.058} \\
\hline Mayo's repair & 1 & 1 & 2 & \\
\hline Mesh repair & 29 & 16 & 15 & \\
\hline
\end{tabular}

\begin{tabular}{|c|c|c|c|c|}
\hline Total & 30 & 20 & 50 & \\
\hline Inference & \multicolumn{4}{|c|}{$\begin{array}{l}\text { There is no statistically significant difference } \\
\text { among the gender }\end{array}$} \\
\hline \multicolumn{5}{|c|}{ Table 15. Surgery Done } \\
\hline
\end{tabular}

\begin{tabular}{|c|c|c|}
\hline & Frequency & Percentage \\
\hline Nil & 47 & 94 \\
\hline Seroma & 01 & 02 \\
\hline Surgical site infection & 01 & 02 \\
\hline Wound dehiscence & 01 & 02 \\
\hline Mesh infection & 0 & 0 \\
\hline Accidental Enterotomy & 0 & 0 \\
\hline Total Table 16. Complication \\
\hline \multicolumn{2}{|c|}{} \\
\hline
\end{tabular}

\begin{tabular}{|c|c|c|c|c|}
\hline & \multicolumn{2}{|c|}{ Gender } & \multirow{2}{*}{ Total } & \multirow{2}{*}{$P$ value } \\
\hline & Female & Male & & \\
\hline Nil & 28 & 19 & 47 & \multirow{5}{*}{0.987} \\
\hline Seroma & 1 & 0 & 1 & \\
\hline $\begin{array}{l}\text { Surgical site } \\
\text { infection }\end{array}$ & 1 & 0 & 1 & \\
\hline $\begin{array}{c}\text { Wound } \\
\text { dehiscence }\end{array}$ & 0 & 1 & 1 & \\
\hline Total & 30 & 20 & 50 & \\
\hline Inference & \multicolumn{4}{|c|}{$\begin{array}{l}\text { There is no statistically significant difference } \\
\text { among the gender }\end{array}$} \\
\hline \multicolumn{5}{|c|}{ Table 17. Complication } \\
\hline
\end{tabular}

\begin{tabular}{|c|c|c|}
\hline & Frequency & Percentage \\
\hline$<10$ days & 16 & 32 \\
\hline $10-20$ days & 30 & 60 \\
\hline $20-30$ days & 01 & 02 \\
\hline$>30$ days & 03 & 06 \\
\hline Total & $\mathbf{5 0}$ & $\mathbf{1 0 0}$ \\
\hline Mean \pm SD & $\mathbf{1 3 . 4 0 \pm 7 . 8 6}(\mathbf{5}-\mathbf{4 6}$ days) \\
\hline \multicolumn{2}{|c|}{ Table 18. Duration of Stay (Days) } \\
\hline
\end{tabular}

\section{ANNEXURES}

Photographs showing Large Incisional Hernia Repair
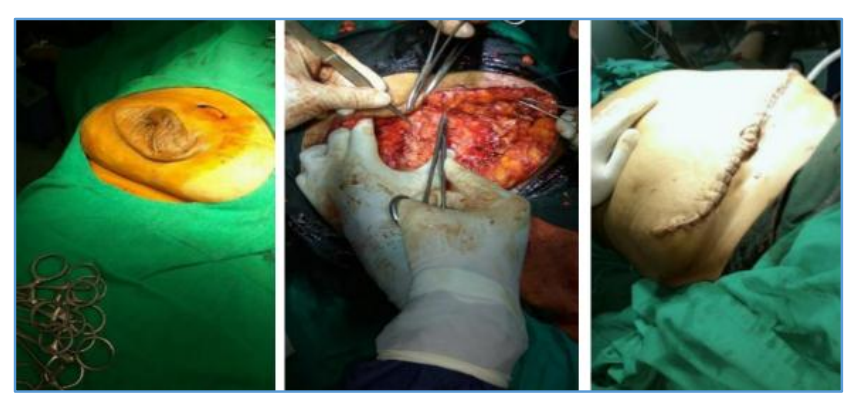

Pictures showing a Huge Incisional Hernia Repair in a previous LSCS Operated Patient

There were no post-operative deaths. No major cardiovascular or pulmonary complications. Mean duration of hospital stay was 13 days (range 5 - 46). Longest duration of stay was seen with those who were medically not fit for surgery at the time of diagnosis and in those who developed complications. Follow-up of patients was done at interval of $1,6,12$ and 18 months. All patients were contacted personally; however, 10 pts. were lost for follow-up, due to inaccessibility. Of all the patients followed up, none developed recurrence during the study period. 


\section{DISCUSSION}

Ventral hernias are a common surgical problem. Millions of patients are affected each year, in incidence it is second only to inguinal hernias accounting for $25 \%$ - $35 \%$ of all hernias. Ventral hernias include incisional and primary defects in the abdominal fascia which can cause umbilical, epigastric or spigelian hernias. In adults, incisional hernias account for $80 \%$ or more of ventral hernias that surgeons repair. The prevalence of incisional hernias after laparotomy is $2 \%$ to $11 \%$ and increases substantially when certain risk factors for post-operative incisional hernia such as a wound infection or obesity are present.

Analysis of a population-based registry revealed that the rate of mesh placement for ventral incisional hernia repair has increased from 35\% in 1987 to $66 \%$ in $1999 .{ }^{2}$ Current practice for the repair of incisional hernias is the selective placement of mesh in patients based on the surgeon's preference and experience. ${ }^{3}$

Incisional hernias accounted for $56 \%$ of ventral hernias. The sex ratio distribution of incisional hernias showed that females were affected more. Ellis $\mathrm{H}$ et al have obtained $64.6 \%$ female population in their study of 342 patients. This female preponderance of incisional hernias could be due to relatively high frequency of employing lower midline incisions, notoriously prone for herniation in women who undergo surgery for pelvic organ pathology.

With respect to umbilical and epigastric hernias, male preponderance was seen.

Certainly, Incisional hernia is not unique to elderly patients, but wound healing is somewhat impaired in patients older than 60 yrs. of age and the incidence in comparable situation is considerably increased with tissues senescence as reported by Robert J Baker.

Majority of the patients who underwent gynaecological procedures (71.4\%) namely Tubectomy- 25\%, LSCS- 35\% and hysterectomy- $40 \%$ developed incision hernia through lower midline incisions.

Clinical experience with polypropylene has demonstrated some complications when it is placed intraperitoneally including adhesion formation, erosion into abdominal viscera and fistula formation. ${ }^{4}$

Solid polytetrafluoroethylene (PTFE) was used for the first time in hernia surgery in 1959. Solid PTFE was plagued by high recurrence rates due to low tensile strength and lack of incorporation within tissue. Expanded PTFE (ePTFE) was later developed in Japan and was used mainly in the intraperitoneal position. Unlike polypropylene, ePTFE has a low incidence of visceral erosion, bowel obstruction, fistulisation and abscess formation, and due to rapid coverage with mesothelium less adhesion formation.5,6

Another strategy to reduce adhesion formation and visceral erosion is the use of composite meshes, which have been shown to form fewer adhesions of weaker strength. ${ }^{7}$

\section{CONCLUSION}

- 50 cases of ventral hernias were studied with follow-up period of 6 to 18 months.

- Incisional hernias constituted $56 \%$ of all ventral hernias.

- Female preponderance was seen in Incisional hernias with male-to-female ratio of 1: 4, whereas in epigastric and umbilical/ paraumbilical hernias male predominance was seen with ratio of 3: 1 and 2: 1 respectively.
- Most of the ventral hernias presented in 4 th to 6 th decades. $90 \%$ of ventral hernias were uncomplicated at the time of presentation.

- Swelling was the most common complaint, pain was seen in $10 \%$.

- Previous surgery was the single most important cause for ventral (Incisional) hernias. Other aetiological factors were multiparity, obesity, anaemia, BPH, alcoholic liver disease and COPD.

- Post-operative wound infection was the important cause for development of Incisional hernias.

- Rare hernias viz. spigelian, gastroschisis and omphalocele were not seen during our study period.

- Mesh repair is the technique of choice for most of Incisional hernias and for all ventral hernias with large defect.

- Mesh repair can be combined with elective bowel surgeries provided with careful preoperative preparation of the patient, meticulous dissection, complete haemostasis and proper post-operative care is given. This still needs further studies.

- Prolene hernia system was primarily developed for repair of inguinal hernias, now-a-days this novel technique is being increasingly employed for the management of epigastric and umbilical hernias also.

- Size of the defect and presence of complication are the guiding factors for choosing the type of repair.

\section{Summary}

Between the periods from December 2015 to September 2017, 50 cases of ventral hernias treated at Basaveshwar Teaching and General Hospital were studied and followed for a period of 6 to 18 months. Ventral hernias were common surgical problems second only to groin hernias. More than $50 \%$ of ventral hernias were incisional followed by epigastric, umbilical and paraumbilical hernias. Most of the incisional hernias developed within 5 years of previous surgery. Swelling, pain and complications along with aesthetic concerns are the causes for seeking surgical solution. Most of ventral hernias were uncomplicated at the time of presentation, remaining presented with obstruction necessitating emergency repair.

Incidence of incisional hernias was more in females with male-to-female ratio of 1: 4, while epigastric and umbilical hernias were more common in males with male-to-female ratio of 3: 1 and 2: 1 respectively. Previous surgery was the single most important cause for ventral (Incisional) hernias. Other aetiological factors were multiparity, obesity, anaemia, $\mathrm{BPH}$, alcoholic liver disease and COPD. Postoperative wound infection was the important cause for development of incisional hernias.

Size of the defect and presence of complication are the guiding factors for choosing the type of repair. Mesh repair is the technique of choice for most of Incisional hernias and for all ventral hernias with large defect. Though sublay/ underlay mesh placement is more physiological, it can be placed either inlay or onlay.

Followup of patients was done at interval of 1, 6, 12 and 18 months. All patients were contacted personally; however, 10 patients were lost for follow-up, due to inaccessibility. Of all the patients followed up, none developed recurrence during the study period. 


\section{REFERENCES}

[1] Read RC. Milestones in the history of hernia surgery: prosthetic repair. Hernia 2004;8(1):8-14.

[2] Flum DR, Horvath K, Koepsell T. Have outcomes of incisional hernia repair improved with time? A population-based analysis. Ann Surg 2003;237(1):129-35.

[3] Courtney CA, Lee AC, Wilson C, et al. Ventral hernia repair: a study of current practice. Hernia 2003;7(1):44-6.

[4] Novitsky YW, Harrell AG, Cristiano JA, et al. Comparative evaluation of adhesion formation, strength of ingrowth, and textile properties of prosthetic meshes after long-term intra-abdominal implantation in a rabbit. J Surg Res 2007;140(1):6-11.
[5] Sikkink CJ, de Reilingh VTS, Malyar AW, et al. Adhesion formation and reherniation differ between meshes used for abdominal wall reconstruction. Hernia 2006;10(3):218-22.

[6] Koehler RH, Begos D, Berger D, et al. Minimal adhesions to ePTFE mesh after laparoscopic ventral incisional hernia repair: reoperative findings in 65 cases. JSLS 2003;7(4):335-40.

[7] Franklin ME, Gonzalez JJ, Glass JL, et al. Laparoscopic ventral and incisional hernia repair: an 11-year experience. Hernia 2004;8(1):23-7. 